UDC 159. 922: 004. 946

DOI: https://doi.org/10.35619/iiu.v0i9.149

\author{
Maria Staworzyńska-Grządziel \\ Doctor PhD \\ Wyższa Szkoła Menedżerska w Warszawie \\ Warszawa, Polska \\ ORCID: 0000-0001-6790-774 \\ e-mail: staworzynska@interia.pl
}

\title{
RZECZYWISTOŚĆ WIRTUALNA A FAŁSZYWA ŚWIADOMOŚĆ MULTIMEDIALNA DZIECKA
}

Adnotacja. Podejmuje się próbę odniesienia się do wirtualnej rzeczywistości (VR) oraz technologii cyfrowych w aspekcie fałszywej świadomości multimedialnej dziecka. Wirtualna rzeczywistość budzi jednak wiele obaw i wątpliwości. Przenoszenie się w inny wymiar pozwala bowiem osiągnąć jedyne w swoim rodzaju doznania, ale może też mieć negatywny wpływ na małego dziecka. System edukacyjny powinien zatem przygotowywać dzieci do tworzenia wiedzy, a nie do korzystania tylko z wiedzy nabytej podczas wykonywania czynności.

Słowa kluczowe: dziecko, fałszywa świadomość multimedialna, gry komputerowe wirtualne, technologie cyfrowe, technologie informatyczne, wirtualna rzeczywistość.

Sformulowanie problemu. $W$ technologii nie ma nic złego pod warunkiem, że przyjmie się wlaściwa...

W wirtualny świat przenieść się można w marzeniach, we śnie, w swego rodzaju wewnętrznej podróży, do której nie jest potrzebny ani komputer, ani inne nowoczesne urządzenia. Ważne, żeby bezbtędnie odróżnić to, co realne $i$ to co wirtualne, bez względu na to, która $\mathrm{z}$ tych rzeczywistości wydaje nam się bardziej atrakcyjna.

Przedstawienie glównego materiału badawczego. HISTORIA WIRTUALNEJ RZECZYWISTOŚCI. Wirtualna rzeczywistość (ang. virtual reality, fantomatyka ) - to obraz sztucznej rzeczywistości stworzony przy wykorzystaniu technologii informatycznej, która polega na multimedialnym kreowaniu komputerowej wizji przedmiotów, przestrzeni i zdarzeń. Obraz ten może reprezentować zarówno elementy świata realnego (symulacje komputerowe), jak i zupełnie fikcyjnego (gry komputerowe science-fiction) (https://www.gryonline.pl/encyklopedia-gier.asp). Prekursorem rzeczywistości wirtualnej jest Myron W. Krueger (ur. 1942) - artysta, badacz i informatyk. Opracował i stworzył on projekty wideoinstalacji, które określał mianem środowisk responsywnych. Pierwszym projektem $M$. W. Kruegera, utworzonym we współpracy z Danem Sandinem, Jerry'm Erdmanem i Richardem Venezky'm był projekt powstały w 1969 roku. Rok później powstaje "Metaplace" łączący przekazy z dwóch pomieszczeń w formę wizualną, którą kształtowały jednocześnie dwie osoby. Najbardziej znaną instalacją M. W. Kruegera stała się jednak "Videoplace" przedstawiona w 1975 roku w Muzeum Sztuki w Milwaukee, będąca rozwinięciem idei "Metaplace". W projekcie tym $M$. W. Krueger położył nacisk na zmysł dotyku, umożliwiając awatarom interakcje na wspólnej przestrzeni wizualnej. Projekt był w kolejnych latach rozbudowywany i wzbogacany o nowe zdobycze techniki. Zastosowano nowe 
oprogramowanie, lepsze komputery oraz akcesoria takie jak hełm i wirtualne rękawice. Roli $M$. W. Kruegera nie sposób przecenić - jego projekty i wizje stały się prototypami systemów rzeczywistości wirtualnej, mających zastosowanie $w$ edukacji, psychologii i psychoterapii. Jednym z takich systemów była powstała 20 lat później (w 1992 roku) instalacja o nazwie „CAVE”.

Za twórcę pojęcia Virtual Reality (VR) uważa się Jarona Laniera - geniusza, który dostał się na uniwersytet w wieku 13 lat (!), a będąc niewiele starszym w swojej firmie VPL Research opracował w pełni działający sprzęt do wirtualnej rzeczywistości - gogle EyePhone i rękawice DataGlove. Wymyślił też nazwę VR Virtual Reality, po czym splajtował - okazując się o wiele lepszym wynalazcą, niż biznesmenem.

Pierwsze wzmianki o wirtualnej rzeczywistości, podobnie jak o innych przełomowych wynalazkach, zanim pojawiły się w urzędach patentowych, opisane zostały w literaturze przygodowej i science-fiction (m.in.: Z Ziemi na Księżyc, Wokót Księżyca i Świat do góry nogami). (W opowiadaniu science-fiction „Pygmalion's Spectacles" znajduje się opis wyposażonego w soczewki i kabel urządzenia, po założeniu którego otrzymujemy sugestywne wrażenie przeniesienia się do innego wymiaru. Efekt miał potęgować wytwarzany sztucznie zapach i możliwość operowania dotykiem.) Z kolei Steve Bryson na podstawie swoich prac w NASA razem z Jaronem Lanierem zdefiniował rzeczywistość wirtualną w następujących słowach: Rzeczywistość wirtualna jest sposobem użycia technologii komputerowej w tworzeniu efektu interaktywnego, trójwymiarowego świata, w którym obiekty dają wrażenie przestrzennej (fizycznej?) obecności. ("Virtual Reality is the use of computer technology to create the effect of an interactive three-dimensional world in which the objects have a sense of spatial presence"). (Burdea \& Coiffe,2003, s. 4148).

Wywodząca się z SF technologia już dekadę od publikacji znalazła się w zasięgu ręki pionierów VR, choć sam termin "wirtualna rzeczywistość" pojawił się znacznie później. W latach 30. XX wieku Stanley G. Weinbaum opisał zastosowanie pierwszych gogli VR (virtual reality). (http://www.komputerswiat.pl/centrumwiedzy-konsumenta/gaming/wszystko-o-wirtualnej-

rzeczywistosci/najpopularniejsze-gogle-vr.aspx).

W 1961 roku w Philco Corporation powstat Headsight - pierwszy w dziejach hetm o rozszerzonej rzeczywistości z zamontowanym ekranem i systemem śledzącym ruchy głowy użytkownika. Ten mógł więc rozglądać się $\mathrm{w}$ interaktywnym wideo. Warto jednak podkreślić, że chodziło tutaj o obserwowanie obrazu wideo w czasie rzeczywistym, kręconego aktualnie przez kamery, a więc nie Virtual Reality. Bell Laboratories znalazło jednak dla tego urządzenia zastosowanie w śmigłowcach wojskowych. Obraz z zamontowanych pod helikopterami kamer był przesyłany do specjalnych hełmów na głowach pilotów. Zanim na rynku pojawiły się typowe gogle VR, Morton Heilig w 1962 roku skończył pracę nad Sensorama - czyli pierwszą wirtualną maszyną VR. Maszyną - a nie goglami, bo ekrany były tylko małą częścią większej konstrukcji, która oferowała jeszcze wibrujące siedzenie czy podmuchy powietrza prosto w twarz użytkownika. Wszystkie filmy kręcone były przez konstruktora Sensoramy i pokazywały akcję w pierwszoosobowym ujęciu, niczym w popularnych dziś grach FPS (First Person Shooter). Prymitywna maszyna sprzed ponad pięćdziesięciu lat oddziaływała na więcej zmysłów, niż dzisiejsze technologie VR. Jednak ze względu na swoje rozmiary i cenę Sensorama nie była dostępna w sprzedaży. Trzy lata po wynalazku Mortona Heiliga, Ivan Sutherland 
zaprezentował gogle Ultimate Display, nazywane też The Sword of Damocles - nie były to zwarte gogle tylko ciężka aparatura, która z racji wagi i rozmiarów została przytwierdzona do sufitu. Zatem patrzący przez soczewki ludzie mieli wrażenie przebywania w innej rzeczywistości (sugestywne wrażenie głębi), co potęgowała technologia przenosząca do symulacji ruchy głowy ( $w$ technologię zainwestowato CIA, a symulatory znalazty też zastosowanie $w$ NASA).

Jeszcze w latach 70 ubiegłego wieku pojawiły się rękawice pozwalające na wchodzenie z wirtualną rzeczywistościa w interakcję (projekt Dana Sandina). Jednak prawdziwy boom na VR miał się dopiero zacząć kilka lat później, wraz z dopracowaniem, zminiaturyzowaniem i zmniejszeniem kosztów. Za popularyzatora tej technologii w latach 80 uważa się Jarona Laniera. Z początkiem lat 90 gry video zagarniają termin „wirtualnej rzeczywistości” na wyłączność, a uwaga wszystkich zwrócona jest na Sege $V R$, która po sukcesie konsoli Genesis zapowiadała mocne wejście w sektor VR. Na zapowiedziach i przedpremierowych pokazach się jednak skończyło. Mimo rozwiniętej technologii i kilku stworzonych z myślą o VR gier, urządzenie nigdy nie trafiło do sprzedaży.( Po latach okazało się, że zabawie z Sega $V R$ towarzyszyły bóle głowy i nudności.) Wstrzymanie premiery tłumaczono obawą o zdrowie graczy. Wirtualna rzeczywistość w wydaniu Segi VR miała być tak realistyczna, że $\mathrm{z}$ goglami na głowie bardzo łatwo było zatracić się i w tej prawdziwej rzeczywistości i wyrządzić sobie krzywdę. VR w wydaniu Segi nigdy nie trafiła pod strzechy. Niszę tę postanowiło wykorzystać Nintendo - wirtualna hybrydowa konsola.

Obecnie istnieją setki firm tworzących gry i aplikacje w rzeczywistości wirtualnej oraz dziesiątki producentów urządzeń, które pozwalają się nimi cieszyć. To jasno pokazuje, że w przyszłości wirtualna rzeczywistość VR może być ważnym elementem naszego życia.

OBAWY I WĄTPLIWOŚCI DOTYCZACE WIRTUALNEJ RZECZYWISTOŚCI. Wirtualna Rzeczywistość, jak każda nowa technologia budzi wiele obaw i wątpliwości. Część z nich jest uzasadniona, a negatywne skutki jej stosowania, czy też nadużywania VR, mogą być poważniejsze niż nam się wydaje. Przenoszenie się w inny wymiar pozwala osiągnąć jedyne w swoim rodzaju doznania, ale może też mieć negatywny wpływ na zdrowie, zwłaszcza tych najmłodszych spośród nas. Nadużywanie VR, może przyczynić się u dziecka do zaburzeń zdrowotnych - najbardziej narażone są dzieci w wieku od 8 do 12 lat (już 20 minutowa zabawa może być niebezpieczna i możemy mówić o zagrożeniach). Wirtualny trójwymiarowy świat jest wyświetlany w urządzeniu VR na dwuwymiarowym ekranie, co stwarza obciążenie dla ludzkiego systemu wzrokowego - tłumaczy Professor Mark Mon-Williams (Professor of Cognitive Psychology, Professor of Vision Science, Buskerud and Vestfold University, Norway). To z tego powodu dziecko może odczuwać bóle oczu i głowy po zabawie w wirtualnej rzeczywistości - tym bardziej że wspomniany ekran jest bardzo blisko oczu ( $u$ dzieci dochodziło do zaburzenia zdolności do wykrywania różnic $w$ dystansach. Innym niepokojącym objawem było drastyczne pogorszenie zachowania równowagi). Niewykluczone jest również i to, że problemów tych nie uda się wyeliminować. Należy jednak pamiętać, że dzieci poniżej szóstego roku życia nie powinny oglądać filmów 3D - zaburza to bowiem ich „naukę” widzenia przestrzennego (http://www.benchmark.pl/aktualnosci/rzeczywistosc-wirtualna-niedla-dzieci.html). 
NAUKA PRZEZ ZABAWE Z VIEW-MASTER. Dziecko poznaje otaczający je świat wszystkimi zmysłami i na swój sposób, bez instrukcji obsługi, empirycznie i szybko rozwijając swą wiedzę oraz umiejętności. To dlatego dzieci łatwiej i zdecydowanie szybciej opanowują sekrety nowoczesnych technologii. W tempie błyskawicznym uczą się używania tabletów, smart fonów czy laptopów. Poprzez zabawę dzieci uczą się najszybciej. Wirtualna rzeczywistość pozwala im na kontakt z symulowanym komputerowo światem i daje szerokie możliwości. Za pośrednictwem panoramicznych zdjęć wykonanych w zakresie 360 stopni oraz materiałów animowanych View-Master - innowacyjny system - zabiera dziecko w podróż do świata wirtualnej rzeczywistości i zachęca do zdobywania wiedzy o ciekawych miejscach, dzikiej przyrodzie, zwierzętach, czy nawet o wszechświecie. Dzieci zyskują błyskawiczny dostęp do twórczego, interaktywnego środowiska edukacyjnego, gdzie zabawa przeradza się w naukę. Technologia 3D umożliwia im oglądanie znanych i ciekawych miejsc bez wychodzenia z domu. Odkrywanie planet i gwiazd jest na wyciągnięcie ręki. Dzieci korzystając z nowych technologii mają szansę pogłębiać swoją wiedzę już nie tylko z kart książek ale być w centrum wydarzeń - to ich przepustka do świata, z tą różnicą, że zamiast zdjęć otacza ich wirtualna rzeczywistość, w którą przenosi Smart Fon - to urządzenie, które naukę zmienia w świetną zabawę dla dziecka. (Aby wkroczyć do niesamowitego wirtualnego świata, potrzeba tylko trzech rzeczy: gogli View-Master, cyfrowej aplikacji lub rozszerzenia View-Master oraz zgodnego Smart Fona z systemem Android). Metodą prób i błędów dzieci szybko uczą się, jak dany przedmiot działa i odkrywają wszystkie jego funkcjonalności. Zdobywanie wiedzy, zapamiętywanie informacji oraz uczenie się - dzieje się niejako przy okazji $i w$ trakcie zabawy. Właśnie dlatego szybciej niż dorosłym, współczesnym dzieciom udaje się opanować używanie nowoczesnych Smart Fonów, laptopów i wielu innych zaawansowanych technologicznie urządzeń. Zatem nowoczesne urządzenie w rękach dziecka od 7 roku życia może służyć nie tylko do zabawy, ale również do nauki.

NOWOCZESNE TECHNOLOGIE CYFROWE A ICH NEGATYWNE SKUTKI. Technologia cyfrowa ma zastosowanie zarówno w dziedzinie użytkowej jak i rozrywkowej. Daje nam narzędzia przy użyciu, których możemy uporać się z poważnymi problemami jakie niesie ze sobą życie i rozwój cywilizacji. Udostępnia również pole dla czystej zabawy intelektualnej, jaką potrafią dać szczególnie dzieciom gry komputerowe. Stymulowanie impulsami wizualnymi 3D szczególnie w dłuższym przedziale czasu może powodować różne reakcje organizmu (np. epilepsje) szczególnie gdy doznania wzrokowe różnią się od grawitacyjnych (błędnik). Ważnym aspektem pozostają również choroby stawów i kręgosłupa. Tablet, komputer czy telewizor to nieodłączne elementy naszego współczesnego życia, jednak im młodsze dziecko, tym większe ryzyko negatywnego wpływu tej technologii na jego prawidłowy rozwój. Odsetek osób korzystających na co dzień z Internetu rośnie w oszałamiającym tempie. W 2007 r. niewiele ponad połowa Polaków miała dostęp do sieci, ale w 2011 roku już w 88\% gospodarstw domowych znajdował się komputer (https: // oczymlekarze.pl/zdrowy-styl-zycia/zdrowie/3545dzieci-w-wirtualnym-swiecie). Dzisiaj niemal w każdym domu można znaleźć sprzęt elektroniczny, który pozwala korzystać z Internetu - laptopa, tabletu i telefonu. Z rozwojem technologicznym nie da się walczyć, a z jego dobrodziejstw najchętniej korzysta młodzież i dzieci. Jednak eksperci na całym świecie alarmują, że coraz młodsze dzieci każdego dnia spędzaja wiele godzin przed ekranami telewizorów, komputerów, tabletów czy smart fonów i nie pozostaje to obojętne dla ich zdrowia - 
szczególnie psychicznego. Nadmiar tego typu bodźców zaburza rozwój mowy, utrudnia wypracowanie uwagi selektywnej, a kiedy staje się substytutem kontaktów międzyludzkich - sprzyja budowaniu społeczeństwa samotników, którzy nie potrafią porozumiewać się ze sobą i budować głębszych relacji w realnym życiu. I chociaż zarówno telewizja, jak i Internet oferują wartościowe programy i gry edukacyjne, niekontrolowane korzystanie $\mathrm{z}$ ich zasobów po prostu zaburza rozwój poznawczy, emocjonalny $i$ społeczny dziecka. Nie mówiąc już o tym, że odciąga to uwagę od innych aktywności, w tym ćwiczeń fizycznych, co przyczynia się choćby do rosnącej epidemii otyłości u najmłodszych.W grupie dzieci rocznych i dwuletnich według (AAP) Amerykańskiej Akademii Pediatrii aż 43\% korzysta z urządzeń mobilnych (smart fon, tablet lub przenośna konsola). W wielu przypadkach robią to bez konkretnego celu, a rodzice najczęściej pozwalają na to, gdy muszą zająć się własnymi sprawami. Tymczasem dzieci poniżej 2 roku życia w ogóle nie powinny korzystać z urządzeń mobilnych. W późniejszym okresie życia kontakt ten należy zwiększać stopniowo, pod baczną obserwacją rodziców, ale maksymalnie do 2 godzin dziennie, ponieważ nadmierne korzystanie z nowoczesnych technologii może prowadzić do problemów z nauką i koncentracją uwagi. Wszystko przez to, że pierwsze 3 lata życia dziecka są kluczowe dla rozwoju jego funkcji psychicznych, a mózg dziecka jest wówczas szczególnie narażony na wpływy środowiskowe. Nadmierna intensywność bodźców nie sprzyja ich porządkowaniu. Dlatego stymulacja za pomocą technologii cyfrowej prawdopodobnie przynosi więcej szkody niż pożytku dla rozwoju poznawczego dziecka.

Obecnie młodzież i dzieci wykorzystują nowoczesne technologie w zasadzie w każdym aspekcie swojego życia, ale jest to znakiem naszych czasów i nie musi nas niepokoić. Nowoczesne technologie informatyczne są po prostu nieodłącznym elementem pracy, nauki, rozrywki i komunikacji. Jak dotąd brakuje jednoznacznej definicji, która wskazałaby, kiedy np. spędzanie czasu w sieci staje się niebezpieczne i przeradza się w uzależnienie. Jednak zdaniem Bohdana Woronowicza, psychiatry i eksperta od uzależnień, można wymienić kilka objawów „siecioholizmu” (Woronowicz, 2009, s.238).

- $\quad$ spędzanie przy komputerze coraz większej ilości czasu kosztem innych zainteresowań,

- zaniedbywanie obowiązków rodzinnych i szkolnych z powodu aktywności W sieci,

- pojawianie się rodzinnych konfliktów związanych z Internetem,

- kłamstwa dotyczące czasu spędzanego w sieci,

- podejmowanie nieudanych prób ograniczenia czasu spędzanego przed komputerem,

- reagowanie rozdrażnieniem, a nawet agresją, w sytuacji utrudnionego dostępu do komputera.

Dzisiejsza młodzież i dzieci żyją w czasach postępującej cyfryzacji. O ile osoby dorosłe stopniowo zapoznawały się $\mathrm{z}$ kolejnymi urządzeniami elektronicznymi - począwszy od czarno-białych telewizorów - o tyle najmłodsi znają je właściwie „od zawsze”. Dlatego eksperci nazywają ich czasem "cyfrowymi tubylcami" w opozycji do rodziców - „cyfrowych imigrantów”. Plusem takiej sytuacji jest fakt, że dzieci dużo łatwiej przyswajają umiejętność korzystania $\mathrm{z}$ technologii. I nie wynika to jedynie $\mathrm{z}$ większej chłonności ich rozwijających się umysłów. Coś, co towarzyszy nam od najmłodszych lat, jest oswojone, naturalne, a korzystamy $\mathrm{z}$ tego intuicyjnie. Nic dziwnego, że dzisiaj telewizja pozostaje 
najważniejszym medium jedynie dla osób powyżej 25 roku życia, ponieważ młodsze osoby stawiają na telefon komórkowy, a młodzież w wieku 15-19 lat wskazuje na pierwszeństwo Internetu.

$\mathrm{Z}$ drugiej strony sytuacja ta niesie pewne zagrożenia. Dzieci od najmłodszych lat przyzwyczajone do spędzania czasu przed ekranami, na których szybko migają kolorowe obrazy, nie odczuwają potrzeby innej stymulacji (Jędrzejczyk, 2014, s. 161-176).

Tradycyjne zabawki i czas spędzany na podwórku wydają im się dużo mniej atrakcyjne. Tymczasem to zabawa odgrywa tak ważną rolę w ich rozwoju - nie tylko przynosi radość, ale również uruchamia wyobraźnię, kształtuje zmysły, rozwija pamięć, spostrzegawczość i inwencję twórczą, przygotowuje do życia, uczy samodzielności i przedsiębiorczości, ale i współpracy w grupie. Przy czym taka autentyczna zabawa wymaga kontaktu zarówno z przyrodą, jak i z rówieśnikami. W zamian za to dzisiaj aż 98\% dzieci w wieku 9-16 lat zamyka się w pokoju, by korzystać m.in. z Internetu przynajmniej raz w tygodniu, a większość z nich robi to codziennie lub prawie codziennie (Raport z badań EU Kids Online II, Polskie dzieci w Internecie. Zagrożenia i bezpieczeństwo, 2011).

Co gorsza dotyczy to również najmłodszych. Dzieci uczą się i poznają świat wykorzystując zarówno swoje zmysły, jak i swój umysł. Jednak w przeciwieństwie do dorosłych nie potrzebują wielu objaśnień, wskazówek czy instrukcji obsługi. Zamiast uczyć się z książki, wolą eksperymentować, próbować i z entuzjazmem doświadczać nowego. Szybko uczą się, jak dany przedmiot działa i odkrywają wszystkie jego funkcjonalności. Zdobywanie wiedzy, zapamiętywanie informacji oraz uczenie się - dzieje się niejako przy okazji, w trakcie zabawy. Właśnie dlatego szybciej niż dorosłym udaje się współczesnym dzieciom opanować używanie nowoczesnych smart fonów, laptopów i wielu innych zaawansowanych technologicznie urządzeń. Nowoczesne urządzenie w rękach dziecka służy nie tylko do zabawy, ale również do nauki. Rodzice dostrzegają potrzebę korzystania ze zdobyczy nowoczesnej technologii w szkole w procesie edukacyjnym dzieci. Uważają, że w przyszłości szkoła będzie lepiej wyposażona w sprzęt elektroniczny, a używanie spersonalizowanych urządzeń elektronicznych w szkole będzie powszechne. W obecnych czasach w niemal każdym aspekcie naszego życia używamy sprzętu elektronicznego. Ich moc i możliwości są tak duże, że mogą one starać się myśleć jak ludzie (sztuczna inteligencja), a także wykreować wizję otaczającego nas świata (wirtualna rzeczywistość). Komputery mogą zapewnić nam rozrywkę poprzez wyglądające realnie gry, jak również pomóc w nauce np. pilotowania samolotu lub przeprowadzania operacji, a wirtualna rzeczywistość może przybliży dzieciom zagadnienie sztucznej rzeczywistości i zwiąanych z nia wyzwań ale i zagrożeń. To, co dzieci obserwują w telewizji czy Internecie, może okazać się negatywnym wzorcem do naśladowania, ponieważ uznawane przez nie wartości i sposób postrzegania świata dopiero się kształtują. Istnieje związek między przemocą na ekranie, a wzrostem agresji w realnym życiu. Dzieci naśladują obserwowane agresywne zachowania i znieczulają się na powszechnie występujące i akceptowalne zjawiska. Potęgują je gry komputerowe szczególnie gry wirtualne, często polegające na zabijaniu przeciwnika. Powoduje to wzrost agresywnych zabaw - zwłaszcza między chłopcami - i próby naśladowania „bohaterów”, których główną zaletą jest siła fizyczna. U dzieci w wieku wczesnoszkolnym światy wirtualny $i$ realny po prostu się przenikaja, a agresywna, krzykliwa dynamika wypacza postrzeganie prawdziwych zdarzeń. Z kolei u najmłodszych dzieci sceny przemocy w wirtualnej 
rzeczywistości mogą prowadzić do koszmarów sennych, zatrzymania rozwoju mowy i zaburzeń natury emocjonalnej. Nie powinno więc dziwić, że nawet wśród osób, u których korzystanie z Internetu wywołuje raczej pozytywny wpływ na psychikę, notuje się wyższy poziom stresu w codziennym życiu. (Jennings Bryant \& Mary Beth Oliver, 2002,s. 49-74).

Rośnie on proporcjonalnie do częstości i długości surfowania. Prawdopodobnie jest to efekt rezygnacji z innych aktywności (np. sportu), które mogłyby obniżać jego odczuwanie.

Jedną z wielkich strat tego pokolenia jest utrata kontaktu z naturą, ponieważ od najmłodszych lat są tak pogrążeni w kulturze technologii cyfrowej, że otaczający ich świat realny wydaje się nudny, pozbawiony uroku i odległy.

DOBRE STRONY WIRTUALNEJ RZECZYWISTOŚCI. Dzieci potrzebują czasu, aby poznać świat taki, jaki jest, a nie taki, jaki może być odwzorowany na ekranie. Bardzo trudno jest im zrozumieć swoją własną naturę i tożsamość, jeśli są od natury oderwane poprzez zanurzenie w wymyślonych środowiskach (Guido Gainotti, 2009).

Należy jednak dostrzec także nieskończone możliwości, jakie daje technologia cyfrowa, oferując olbrzymi skład pamięci do tworzenia $i$ przetwarzania kultury. Eugene Gan, autor pozycji zatytułowanej „Nieskończone pasmo: napotkanie Chrystusa w mediach, (Eugene Gan: 2010, s. 105) skupia się na pozytywnym potencjale wirtualnej rzeczywistości VR i wszystkich innych technologiach cyfrowych. W rzeczywistości wirtualnej jest jakieś piękno i dlatego ona przyciąga ludzi - mówi profesor Uniwersytetu Franciszkańskiego w Steubenville. Eugene Gan doradza także rodzicom, by doświadczali rzeczywistości wirtualnej razem ze swoimi dziećmi, zamiast je nawracać i perorować o zagrożeniach. Istnieją również zastosowania terapeutyczne wirtualnej rzeczywistości o dużym potencjale, w tym możliwość leczenia z zespołem stresu pourazowego.

Wnioski i perspektywy dalszych badań. Dzieciństwo - to świat przeżyć i aktywności dziecka, zachowań i relacji z innymi osobami (rodzicami, rówieśnikami, innymi ludźmi) oraz skutki tych relacji. Dzieciństwo naznaczone jest również zmianami o charakterze destrukcyjnym. Dotyczą one sfer osobowości i są skutkiem określonych relacji, jakie zachodzą między mass mediami a dzieckiem. Zmiany te tworzą określoną świadomość medialna, wywołującą relatywizm poznawczy, moralny, co w konsekwencji prowadzi do bierności i postawy ślepego naśladownictwa. Zmienia się więc zakres przeżyć, doświadczeń i jakość odbieranych wzorców mających wpływ na wychowanie dziecka. Dostrzeganie tego rodzaju zagrożeń jest sprawą ważną przede wszystkim dla rodziców i wychowawców. Należy pamiętać o tym, że dziecka w żaden sposób nie wychowają media. Dziecko musi czerpać odpowiednie wzorce i postawy z zachowań najbliższego otoczenia; Ograniczając dostęp do mediów należy dziecku coś w zamian zaproponować. Nic nie zastąpi domu rodzinnego, w którym dziecko przegląda się jak w zwierciadle. Z pewnością chcemy, by nasze dzieci nauczyły się krytycznej analizy przekazów medialnych, potrafiły krytycznie spojrzeć na strukturę i znaczenia tekstów, a także na metody konsumpcji i strategie interpretacyjne. Należy jednak uważać, aby nie zaszczepić $w$ młodych ludziach zbyt negatywnej wizji mediów - nie można więc dopuścić do tego, by dzieci podchodzity do mediów podejrzliwie. Powinniśmy stworzyć dzieciom takie warunki, które pozwolą im na swobodną, pomysłową, dobrze zaprojektowaną twórczość medialną, wyrażającą ważne dla nich przesłania, które będą wykorzystywać dostępne im zasoby. Powinniśmy krzewić wśród dzieci 
odpowiednie podejście do mediów, literatury, sztuki i muzyki - najprościej określane mianem ,krytycznego uznania”.

Dziecko, żyjące w świecie wirtualnym należy rozumieć, jako dziecko przebywające w świecie nierzeczywistym, potencjalnym świecie cechującym się doskonałością i siłą przyciągania. Świat taki tworzą wytwory, powstające na podstawie ludzkiej wyobraźni, przy użyciu zaawansowanych technologii komputerowych. Dostęp do tego świata umożliwiają właśnie gry wirtualne. Wszyscy powinniśmy mieć świadomość tego, że istnieje realne niebezpieczeństwo płynące $\mathrm{z}$ gier wirtualnych. Wzrasta również poziom cyberprzestępczości związanej z grami on-line. Świat wirtualny jest dla dzieci pociągający, pełen tajemnic, ale też niebezpieczny i wprowadzający w nieznany krąg gier i kontaktów międzyludzkich. Spirala wirtualnego świata nakręca się i dziecko często robi się kapryśne, znudzone, zaczyna oszukiwać odnośnie do czasu spędzonego przy ekranie komputera, szuka sobie kolegów, z którymi można pograć i porozmawiać przez komunikatory. Życie dziecka zaczyna rozgrywać się we wspólnych walkach z potworami albo budowaniu pałaców czy przerażających pomieszczeń. Dziecko przestaje odróżniać fikcję od rzeczywistości, staje się bierne pod względem intelektualnym oraz mniej twórcze. Obserwuje się również zmiany w rozwoju mowy, która w wieku wczesnoszkolnym dopiero się rozwija. Doprowadza to wręcz do ogólnego uczucia zagubienia, zaburzeń procesów pamięciowych oraz pojawiania się natrętnych myśli (Tanaś, 1993, s. 12).

Kontakt dziecka ze światem wirtualnym stwarza niewątpliwie nowe możliwości rozwojowe, choć jednocześnie niesie zagrożenia. Należy zatem zawsze rozważyć wartości rozwijające i zagrożenia, jakie niosą poszczególne rodzaje środków, umożliwiających dostęp do wirtualnego świata. Ponadto różnorodność treści płynących z sieci tworzy wymieszany obraz faktów i mitów, sprawia to, iż świat wirtualny staje się dla dziecka bardziej realny od rzeczywistego, a to wyzwala w dziecku postawę ślepego naśladowania agresji oraz biernej postawy (Izdebska, 2004, s. 380-385). Wirtualna rzeczywistość ukazuje dziecku świat w sposób niezwykle zróżnicowany, lansując beztroskę, przemoc bądź okrucieństwo. Konfrontacja doświadczeń fikcyjnych bohaterów z własnymi może być frustrująca bądź pobudzająca do działań twórczych (Jandy-Brudło, 1993, .s. 205).

Szczególną wartość edukacyjną mają oglądane przez dzieci cykliczne programy adresowane do młodszych odbiorców, programy przyrodnicze, popularnonaukowe czy informacyjne. Wiele tych programów cyklicznych dla dzieci prezentuje bogatą i urozmaiconą tematykę i są one prowadzone $z$ udziałem dzieci. Wywołuje to zainteresowanie wśród najmłodszych. Media stają się więc znaczącym ogniwem środowiska wychowawczego, tworząc nowe możliwości, szanse rozwoju i edukacji dziecka.

Pochodzące sprzed lat rozwiązania stanowią tylko małą część wirtualnej rzeczywistości VR, a zapowiadane były przecież na samodzielne i rewolucyjne urządzenia. Pytanie, czy reklamowana w podobnych tonach technologia wirtualnej rzeczywistości nie skończy tak samo - kończąc zanim na dobre się zaczęła? Technologia cyfrowa bowiem niesie ze sobą wyzwania w odniesieniu do większości dziedzin życia, ale szczególnie duże i znaczące w odniesieniu do edukacji. Wynika to $\mathrm{z}$ dominującej roli wiedzy $\mathrm{w}$ globalnym społeczeństwie informacyjnym. Wyzwaniem dla edukacji jest konieczność wykształcenia zdecydowanej większości społeczeństwa na poziomie nazywanym dzisiaj „wyższym” oraz konieczność znacznie częstszego odnawiania i poszerzania wiedzy, która będzie z jednej strony szybko dezaktualizować się, a z drugiej - szybko przyrastać. System edukacyjny 
musi przygotować ludzi nie do korzystania z nabytej wiedzy podczas wykonywania powtarzalnych czynności, ale do tworzenia wiedzy. Ta umiejętność jest dzisiaj zarezerwowana dla nielicznych, a musi być zaoferowana szerokim warstwom społeczeństwa. Wielkim wyzwaniem, przed którym dziś stoi edukacja jest stawienie czoła zmienności i przyrostowi, a zadaniem pedagogów jest strzeżenie dziecka przed pozornymi wartościami i pretensjonalnością form, jakie podsuwa nam kultura nowych technologii cyfrowych.

\section{LISTA UŻYWANYCH ŹRÓDEL:}

https://www.gry-online.pl/encyklopedia-gier.asp enezky

https://www.google.com/search?q=Dan+Sandin\%2C+Jerry+Erdman+i+Richard+V

Burdea, G. \& Coiffet, P. (2003). Technologia Wirtualnej rzeczywistości [Virtual Reality Technology], John Wiley \& Sons, inc. New York, NY, USA, s. 41-48 [in Polish].

http://www.komputerswiat.pl/centrum-wiedzy-konsumenta/gaming/wszystko-owirtualnej-rzeczywistosci/najpopularniejsze-gogle-vr.aspx

http://www.benchmark.pl/aktualnosci/rzeczywistosc-wirtualna-nie-dla-dzieci.html swiecie

https://oczymlekarze.pl/zdrowy-styl-zycia/zdrowie/3545-dzieci-w-wirtualnym-

Woronowicz, B. (2009). Uzależnienia. Geneza, terapia, powrót do zdrowia. Wyd. Media Rodzina, Warszawa, s.238. [in Polish]

Jędrzejczyk, I. (2014). Telewizja a zabawy dowolne dzieci. Pedagogika Przedszkolna i Wczesnoszkolna, Nr 1 (3): ss.161-176. [in Polish]

Raport z badań EU Kids Online II, Polskie dzieci $w$ Internecie. Zagrożenia $i$ bezpieczeństwo. (2011), część 2. Warszawa. [in Polish]

Jennings Bryant, J., Oliver, M. (2002). Media Effects: Advances in Theory and Research, J Soc Iss. 58 (1): 49-74. [in English]

Gainotti, G. (2009). Neuropsychologia, 1765-2014 ; volume 47 (8-9). [in English].

Gan E. (2010). Nieskończone pasmo: napotkanie Chrystusa $w$ mediach (Infinite Bandwidth: Encountering Christ in the Media). Emmaus Road Publishing, s. 105. [in Polish].

Tanaś, M. (1993). Medyczne skutki uboczne kształcenia wspomaganego komputerowo. „Toruńskie Studia Dydaktyczne”, nr 3, s. 12.

Izdebska, J. (2004). Rodzinna edukacja medialna dziecka // w : Kompetencje medialne społeczeństwa wiedzy, red. Wacław Strykowski, Wojciech Skrzydlewski. Poznań : Wydawnictwo eMPI2, s. 380-385. [in Polish].

Jandy-Brudło, E. (1993). Wpływ telewizji na agresywne zachowanie dzieci i młodzieży. Problemy Opiekuńczo-Wychowawcze, nr 5.s. 205. [in Polish]

Bednarek, J., Andrzejewska, A. (2009). Cyberświat - możliwości i zagrożenia. Wydawnictwo Akademickie Żak, Warszawa. [in Polish]

Danowski, B., Krupińska A. (2007). Dziecko w sieci Wyd. Helion, Gliwice. [in Polish].

Gajda, J. (2002). Media w edukacji. Oficyna Wydawnicza Impuls, Kraków. [in Polish].

Izdebska, J. (2005). Dziecko i media elektroniczne - nowy wymiar dzieciństwa. Wyd. Tran Humana. Białystok.

Siemieniecki, B. (2007). Media w pedagogice [w:] Pedagogika medialna. Podręcznik akademicki. Tom I. Warszawa. PWN.

Jandy-Brudło, E. (1993). Wpływ telewizji na agresywne zachowanie dzieci i młodzieży// w: Problemy Opiekuńczo-Wychowawcze, nr 5. 
Jędrzejczyk, I. 92014). Telewizja a zabawy dowolne dzieci, Pedagogika Przedszkolna i Wczesnoszkolna, $\mathrm{Nr} 1$ (3).

Kondracka, M. (2008). Realne zagrożenia wirtualnych relacji dziecko - media elektroniczne Nowa szkoła $\mathrm{Nr} 2$.

Tabor S. (2004). Niebezpieczny Internet. Życie szkoty, Nr 8.

\section{REFERENCES:}

https://www.gry-online.pl/encyklopedia-gier.asp enezky

https://www.google.com/search?q=Dan+Sandin $\% 2 \mathrm{C}+\mathrm{Jerry}+$ Erdman+i+Richard $+\mathrm{V}$

Burdea, G. \& Coiffet, P. (2003). Technologia Wirtualnej rzeczywistości [Virtual Reality Technology], John Wiley \& Sons, inc. New York, NY, USA, s. 41-48 [in Polish].

http://www.komputerswiat.pl/centrum-wiedzy-konsumenta/gaming/wszystko-owirtualnej-rzeczywistosci/najpopularniejsze-gogle-vr.aspx

http://www.benchmark.pl/aktualnosci/rzeczywistosc-wirtualna-nie-dla-dzieci.html swiecie

https://oczymlekarze.pl/zdrowy-styl-zycia/zdrowie/3545-dzieci-w-wirtualnym-

Woronowicz, B. (2009). Uzależnienia. Geneza, terapia, powrót do zdrowia. [Addiction. Genesis, Therapy, Recovery]. Wyd. Media Rodzina, Warszawa, s.238. [in Polish]

Jędrzejczyk, I. (2014). Telewizja a zabawy dowolne dzieci. [Television and Games for any Children]. Pedagogika Przedszkolna i Wczesnoszkolna, $\mathrm{Nr} 1$ (3): ss.161-176. [in Polish].

Raport z badań EU Kids Online II, Polskie dzieci w Internecie. Zagrożenia $i$ bezpieczeństwo [EU Kids Online II research report, Polish children on the Internet. Threats and security]. (2011), część 2. Warszawa. [in Polish]

Jennings Bryant, J., Oliver, M. (2002). Media Effects: Advances in Theory and Research, J Soc Iss. 58 (1): 49-74. [in English]

Gainotti, G. (2009). Neuropsychologia, 1765-2014 ; volume 47 (8-9). [in English].

Gan E. (2010). Nieskończone pasmo: napotkanie Chrystusa $w$ mediach [Infinite Bandwidth: Encountering Christ in the Media], Emmaus Road Publishing, s. 105. [in Polish].

Tanaś, M. (1993). Medyczne skutki uboczne kształcenia wspomaganego komputerowo. [Medical Side Effects of Computer-aided Education]. Toruńskie Studia Dydaktyczne, nr 3, s. 12. [in Polish]

Izdebska, J. (2004). Rodzinna edukacja medialna dziecka [Family Media Education of a Child] // w : Kompetencje medialne społeczeństwa wiedzy, red. Wacław Strykowski, Wojciech Skrzydlewski. - Poznań : Wydawnictwo eMPI2, s. 380-385. [in Polish]

Jandy-Brudło, E. (1993). Wpływ telewizji na agresywne zachowanie dzieci i młodzieży [Influence of Television on Aggressive Behavior of Children and Youth]. Problemy Opiekuńczo-Wychowawcze, nr 5.s. 205. [in Polish]

Bednarek J., A. Andrzejewska A. (2009). Cyberświat - możliwości i zagrożenia, [Cyberbulb - Opportunities and Threats]. Wydawnictwo Akademickie Żak, Warszawa. [in Polish]

Danowski, B., Krupińska A. (2007). Dziecko w sieci [Child on the Web]. Wyd. Helion, Gliwice . [in Polish]

Gajda, J. (2002). Media w edukacji [Media in Education]. Oficyna Wydawnicza Impuls, Kraków. [in Polish]

Izdebska, J. (2005). Dziecko i media elektroniczne - nowy wymiar dzieciństwa [Child and Electronic Media - a New Dimension of Childhood]. Wyd. Tran Humana. Białystok. [in Polish] 
Siemieniecki, B. (2007). Media w pedagogice [Media in Pedagogics] / w: Pedagogika medialna. Podręcznik akademicki. Tom I. Warszawa. PWN.

Jandy-Brudło E. (1993). Wpływ telewizji na agresywne zachowanie dzieci i młodzieży [Influence of Television on the Aggressive Behavior of Children and Adolescents] / w: Problemy Opiekuńczo-Wychowawcze, nr 5. [in Polish]

Jędrzejczyk, I. 92014). Telewizja a zabawy dowolne dzieci [Television and Games for any Children]. Pedagogika Przedszkolna i Wczesnoszkolna, $\mathrm{Nr} 1$ (3). [in Polish]

Kondracka, M. (2008). Realne zagrożenia wirtualnych relacji dziecko - media elektroniczne [Real Threats to Virtual Child-electronic Media Relations]. Nowa szkoła $\mathrm{Nr}$ 2. [in Polish]

Tabor S. (2004). Niebezpieczny Internet [Dangerous Internet]. Życie szkoty, Nr 8. [in Polish]

\title{
ВІРТУАЛЬНА РЕАЛЬНІСТЬ І ХИБНА МУЛЬТИМЕДІЙНА СВІДОМІСТЬ ДИТИНИ
}

\author{
Марія Ставожинська-Гжоуджель \\ доктор наук Вищої школи менеджменту у Варшаві, \\ м. Варшава, Польща \\ ORCID: 0000-0001-6790-774 \\ e-mail: staworzynska@interia.pl
}

\begin{abstract}
Анотація. Виконана спроба оцінювання віртуальної реальності (ВР) та цифрових технологій в аспекті хибної мультимедійної свідомості дитини. Віртуальна реальність, як і будь-яка нова технологія, заслуговує на вивчення іiі навчально-виховних можливостей щодо підвищення ефективності педагогічного процесу, проте у вчителів викликає багато сумнівів. Деякі можливості виправдані, але негативні наслідки використання ВР та зловживання можуть бути більш серйозними, ніж ми очікуємо. Перехід в інший вимір дозволяє досягти унікального досвіду, але він також може негативно вплинути на здоров'я, особливо маленької дитини. Віртуальна реальність - це картина штучної реальності, створена 3 використанням інформаційних технологій, яка полягає в створенні мультимедійного комп'ютерного бачення об’єктів, простору і подій. Цей образ може представляти обидва елементи: і реального світу, і повністю вигаданий. Тому система освіти повинна готувати дітей і молодь до проектування знань, а не тільки використовувати такі, що отримані під час їх життєдіяльності. Таким чином, величезною проблемою, з якою стикається сьогодні в першу чергу дошкільна $і$ початкова освіта, $€$ готовність адекватно приймати і використовувати нові навчальні технології, пов'язані 3 віртуальною реальністю, і завдання вчителявихователя - захистити дитину від уявних цінностей і претензійності форм, які пропонує нам культура нових цифрових технологій.

Ключові слова: дитина, хибна мультимедійна свідомість, віртуальні комп'ютерні ігри, цифрові технології, інформаційні технології, віртуальна реальність.
\end{abstract}

\section{VIRTUAL REALITY AND FALSE MULTIMEDIA OF A CHILD}

Maria Staworzyńska-Grządziel

Doctor PhD Higher School of Management in Warsaw, Warsaw, Poland

ORCID: 0000-0001-6790-774 


\begin{abstract}
An attempt was made to assess virtual reality (VR) and digital technologies in the aspect of false multimedia consciousness of the child. Virtual reality, like any new technology, deserves the study of its educational and educational opportunities to increase the efficiency of the pedagogical process, but it raises many fears and doubts. Some possibilities are justified, but the negative effects of its use and abuse can be more serious than we expect. Moving to another dimension allows you to achieve a unique experience, but it can also adversely affect the health, especially the baby. Virtual reality is a picture of artificial reality, created using information technology, which is to create a multimedia computer vision of objects, space and events. This image can represent both elements: and the real world, and completely fictitious. Therefore, the education system should prepare children and young people for the design of knowledge, and not only use those acquired during their lifetime. Thus, the huge problem facing today, primarily pre-school and primary education, is the willingness to adequately accept and use the new educational technologies associated with virtual reality, and the task of the teacher-educator - to protect the child from the imaginary values and pretentiousness of the forms, which offers us the culture of new digital technologies. Childhood is a world of childhood experiences and activities, behaviors and relationships with other people (parents, peers, other people) and the effects of these relationships. Childhood is also marked by destructive changes. They concern the spheres of personality and are the result of specific relations that take place between the mass media and the child. These changes create a specific media awareness that evokes cognitive and moral relativism, which in turn leads to passivity and an attitude of blind imitation. We should create conditions for children that allow them to have free, imaginative, well-designed media creativity, expressing important messages for them that will use the resources available to them. We should promote appropriate approaches to the media, literature, art and music among children - simply referred to as "critical recognition".
\end{abstract}

Key words: child, fake multimedia consciousness, virtual computer games, digital technologies, information technologies, virtual reality.

Стаття надійшла до редакиї 20.03.2019 р. 